\title{
Deteksi Penyakit Covid-19 Berdasarkan Citra X-Ray Menggunakan Deep Residual Network
}

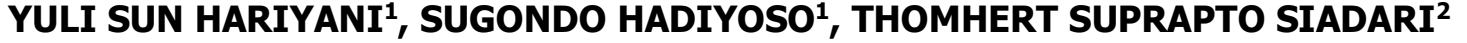 \\ ${ }^{1}$ Universitas Telkom, Indonesia \\ 2 University of Science and Technology, Republic of Korea \\ Email: yulisun@telkomuniversity.ac.id
}

Received 30 Maret 2020 | Revised 10 April 2020 | Accepted 10 Mei 2020

\begin{abstract}
ABSTRAK
Penyakit Coronavirus-2019 atau Covid-19 telah menjadi pandemi global dan menjadi masalah utama yang harus segera dikendalikan. Salah satu cara yang dapat dilakukan adalah memutus rantai penyebaran virus tersebut dengan melakukan deteksi dan melalukan karantina. Pencitraan X-Ray dapat dijadikan alternatif dalam mempelajari Covid-19. X-Ray dianggap mampu menggambarkan kondisi paru-paru pada pasien Covid-19 dan dapat menjadi alat bantu diagnosa klinis. Pada penelitian ini, kami mengusulkan pendekatan deep learning berbasis residual deep network untuk deteksi Covid-19 melalui citra chest X-Ray. Evaluasi yang dilakukan untuk mengetahui performa metode yang diusulkan berupa precision, recall, F1, dan accuracy. Hasil eksperimen menunjukkan bahwa usulan metode ini memberikan precision, recall, $F 1$ dan accuracy masing-masing 0,98, 0,95, 0,97 dan 99\%. Pada masa mendatang, studi ini diharapkan dapat divalidasi dan kemudian digunakan untuk melengkapi diagnosa klinis oleh dokter.
\end{abstract}

Kata kunci: Coronavirus-2019, Covid-19, chest X-Ray, deep learning, residual network

\section{ABSTRACT}

Coronavirus-2019 or Covid-19 disease has become a global pandemic and is a major problem that must be stopped immediately. One of the ways that can be done to stop its spreading is to break the spreading chain of the virus by detecting and doing quarantine. X-Ray imaging can be used as an alternative in detecting Covid-19. X-Ray is considered able to describe the condition of the lungs for Covid-19 suspected patients and can be a supporting tool for clinical diagnosis. In this study, we propose a residual based deep learning approach for Covid-19 detection using chest X-Ray images. Evaluation is carried out to determine the performance of the proposed method in the form of precision, recall, F1 and accuracy. Experiments results show that our proposed method provides precision, recall, F1 and accuracy respectively $0.98,0.95,0.97$ and $99 \%$. In the future, this study is expected to be validated and then used to support clinical diagnoses by doctors.

Keywords: Coronavirus-2019, Covid-19, chest X-Ray, deep learning, residual network 
Hariyani, dkk.

\section{PENDAHULUAN}

Penyakit Coronavirus-2019 atau dikenal dengan Coronavirus Disease-2019 (COVID-19) adalah penyakit menular akut yang disebabkan oleh virus corona jenis baru (Boldog, dkk, 2020). Penyakit ini menyerang sistem pernapasan secara akut dengan gejala seperti demam, kelelahan, batuk kering dan sesak napas (Liu, dkk, 2020)(Wang, dkk, 2020). Gejala lainnya dapat berupa nyeri otot, produksi dahak, diare, dan sakit tenggorokan. COVID-19 pertama diketahui pada Desember 2019 di Wuhan, China (Huang, dkk, 2020). Dalam kurun waktu 3 bulan menjadi pandemi global (Mckeever, 2020). Berdasarkan laman https://www.worldometers.info/ coronavirus/ yang diakses pada tanggal 23 maret 2020, penyakit ini dilaporkan telah menyebar di 19 negara dengan total penderita sebanyak 351.198 orang. Lebih dari 15.000 orang meninggal dunia karena Covid-19. Ini merupakan ancaman serius bagi negaranegara di dunia yang dapat mengganggu bahkan menghancurkan berbagai sektor kehidupan. Saat ini Covid-19 menjadi musuh bersama yang harus diperangi agar kondisi terburuk tidak dialami.

Beberapa strategi telah diterapkan untuk menekan laju pertambahan penderita yang relatif sangat cepat. Usaha untuk menolak penyakit ini sangatlah sulit atau bahkan tidak mungkin, namun kita dapat menekan laju pertumbuhan yang cepat ini agar seimbang dengan kemampuan perawatan medis. Dengan demikian angka kematian dapat diturunkan. Strategi tersebut termasuk pelacakan asal mula penderita, isolasi kota/negara dan atau melakukan tes masal. Saat ini diagnosis utama ditegakkan melalui uji polymerase chain reaction (PCR) dan swab tenggorokan ditambah dengan pendekatan konfirmasi untuk memberikan diagnosa yang akurat (Wang, dkk, 2020). Namun demikian, metode ini membutuhkan waktu dan biaya yang tidak sedikit. Proses diagnosa atau screening awal tidak mungkin menggunakan metode tesebut. Cara lain yang dapat dipertimbangkan adalah tindakan non-invasive melalui pencitraan paru karena mengacu pada gejala yang ditimbulkan yaitu sesak nafas sebagai akibat pneumonia akut.

Metode alternatif antara lain pencitraan CT dan X-Ray. Penelitian mengenai penggunaan CT imaging untuk deteksi atau analisis tingkat keparahan Covid-19 ini telah dilakukan oleh beberapa peneliti. Penelitian oleh Liu., dkk mengevaluasi tingkat keparahan Covid-19 pada 73 pasien menggunakan modalitas pencitraan CT (Liu, dkk, 2020). Penelitian ini memberikan kesimpulan bahwa tingkat keparahan penyakit memberikan gambaran CT yang berbeda. Studi lainnya oleh Hosseiny., dkk juga menitikberatkan penggunaan CT untuk analisis Covid-19 ini (Hosseiny, dkk, 2020). Pencitraan CT pada kasus Covid-19 untuk analisis kondisi pasien yang diobati telah dilaporkan oleh Yoon., dkk (Yoon, dkk, 2020). Penelitian lain oleh Zhu., dkk, mengemukakan bahwa citra CT bagian dada dapat memberikan informasi tentang infeksi ini (Zhu, dkk, 2020). Xu., dkk, mengusulkan pendekatan deep learning untuk deteksi Covid-19 melalui citra CT (Xu, dkk, 2020). Penelitian oleh Xu memberikan akurasi kurang dari $90 \%$ untuk tiga kelompok: Covid-19, pneumonia virus Influenza-A dan normal. Meskipun teknik pencitraan CT mempunyai peluang yang bagus dalam menganalisis Covid-19, teknik ini memerlukan biaya dan pengaturan perangkat yang tidak murah. Ini akan membutuhkan sumber daya besar jika diterapkan untuk screening pada populasi yang besar. Radiografi berbasis CT umumnya hanya tersedia pada rumah sakit pusat atau kelas pertama. Oleh karena itu baru-baru ini pencitraan X-Ray menjadi perhatian peneliti untuk dijadikan alternatif dalam mempelajari Covid-19. X-Ray dianggap mampu menggambarkan kondisi paru-paru pada pasien Covid-19 dan dapat menjadi alat bantu diagnosa klinis. Penelitian yang dilakukan oleh Narin, dkk menggunakan deep learning untuk mengklasifikasi Covid-19 dan kondisi normal (Narin, dkk, 2020). Namun demikian, pada penelitian tesebut menggunakan data uji yang sangat terbatas, hanya 10 citra untuk masing-masing kelas. Dalam tulisan ini, kami mengusulkan pendekatan deep learning berbasis residual network untuk deteksi Covid-19 melalui citra chest X-Ray. Evaluasi dilakukan untuk mengetahui performa 
metode yang diusulkan berupa precision, recall, F-1, dan akurasi. Dengan metode yang kami usulkan diharapkan dapat memberikan gambaran yang lebih komprehensif dalam tujuan membantu dan melengkapi diagnosa klinis serta perawatan pasien.

\section{METODOLOGI}

\subsection{Convolutional Neural Network (CNN)}

Dalam beberapa tahun ke belakang, penggunaan deep learning khususnya convolutional neural network (CNN) berhasil mengungguli performansi machine learning tradisional dalam bidang klasifikasi citra, tidak terkecuali citra medis (Allaouzi, dkk, 2019). Banyak variasi arsitektur jaringan yang dibangun dari CNN, antara lain Inception (Singh, dkk, 2019), VGGNet (Simonyan \& Zisserman, 2019), MobileNet (Howard, dkk, 2019), Densenet (Huang, dkk, 2017), dsb. CNN pada dasarnya adalah susunan banyak layer yang terdiri dari convolution layer, pooling layer, dan fully connected layer. Berbeda dengan jaringan syaraf tiruan biasa seperti yang terlihat pada Gambar 1, CNN mengatur neuron sehingga memiliki tiga dimensi (lebar, tinggi dan kedalaman) yang pada Gambar 1 didefinisikan sebagai satu layer. Setiap layer pada CNN mentransformasi input 3D menjadi output 3D dari aktivasi neuron.

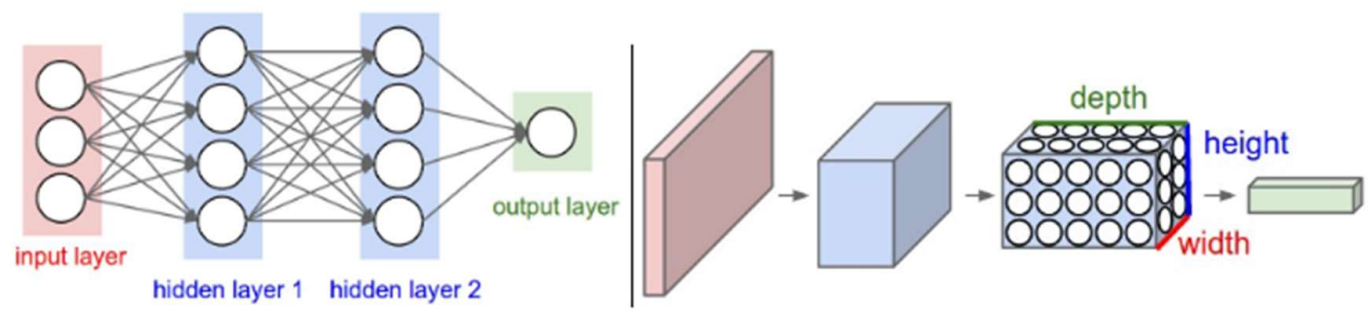

Gambar 1. Jaringan Saraf Tiruan (kiri) dan CNN (kanan)

\subsubsection{Convolution Layer}

Pada convolution layer dilakukan ekstraksi fitur pada citra dengan melakukan proses konvolusi antara filter matrix dengan input citra. Dengan penggunaan banyak tingkat layerdan filter matrix yang berbeda, maka akan didapatkan fitur di level tinggi seperti edge, curve dan fitur warna.

\subsubsection{Pooling Layer}

Pooling layer digunakan untuk mengurangi ukuran spasial dengan tujuan mengurangi jumlah parameter dan komputasi, selain itu juga untuk menghindari kondisi overfitting dimana model sangat akurat memprediksi data latih namun gagal mengenali data di luar data latih. Jenis pendekatan pooling yang banyak digunakan yaitu max pooling dan average pooling. Max pooling mengambil nilai maksimum pada daerah tertentu, sedangkan average pooling mengambil nilai rata-rata.

\subsubsection{Fully Connected Layer}

Fully connected layer adalah jaringan syaraf tiruan feedforward yang terdiri dari input layer, hidden layer dan output layer, dimana setiap neuron pada suatu layer terhubung secara penuh ke neuron pada layer sebelum dan setelahnya.

\subsection{Residual Network}

Masalah yang dialami arsitektur CNN sebelumnya adalah ketika jaringan mulai konvergen dan kedalaman jaringan bertambah maka akurasi akan mengalami nilai saturasi kemudian menurun secara cepat. Residual Network (ResNet) yang diperkenalkan oleh (He, dkk, 2016) 
menambahkan skip connection atau identity mapping pada jaringan CNN untuk mengatasi masalah tersebut. Mekanisme 'skip connection' atau identity mapping dapat dilihat pada Gambar 2. Identity mapping $\mathrm{x}$ akan melompati beberapa layer kemudian ditambahkan pada output layer F di depan nya.

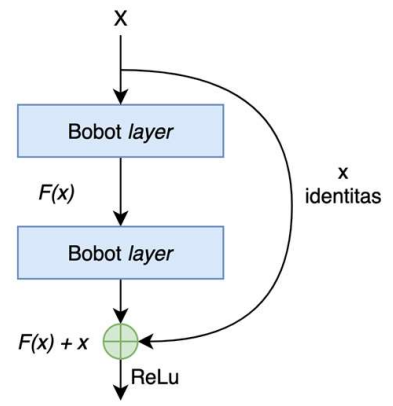

\section{Gambar 2. Blok Residual}

ResNet yang digunakan pada penelitian ini adalah ResNet-50 yang memiliki 50 layer seperti yang ditunjukkan pada Gambar 3. Selain ResNet-50, beberapa tipe arsitektur ResNet lain diantaranya ResNet-18, ResNet-34, ResNet-101 hingga ResNet-152. Seperti yang telah disebutkan sebelumnya bahwa dasar dari arsitektur ResNet adalah CNN, sehingga layer-layer ResNet-50 juga terdiri dari convolutional layer, pooling layer, dan fully connected (fc) layer serta penambahan skip connection pada setiap beberapa convolution layer. Di akhir, ResNet menggunakan fungsi softmax sebagai fungsi aktivasi. Fungsi softmax dapat dilihat pada Persamaan 1.

$$
\operatorname{softmax}\left(z_{j}\right)=\frac{\exp \left(z_{j}\right)}{\sum \exp \left(z_{i}\right)}
$$

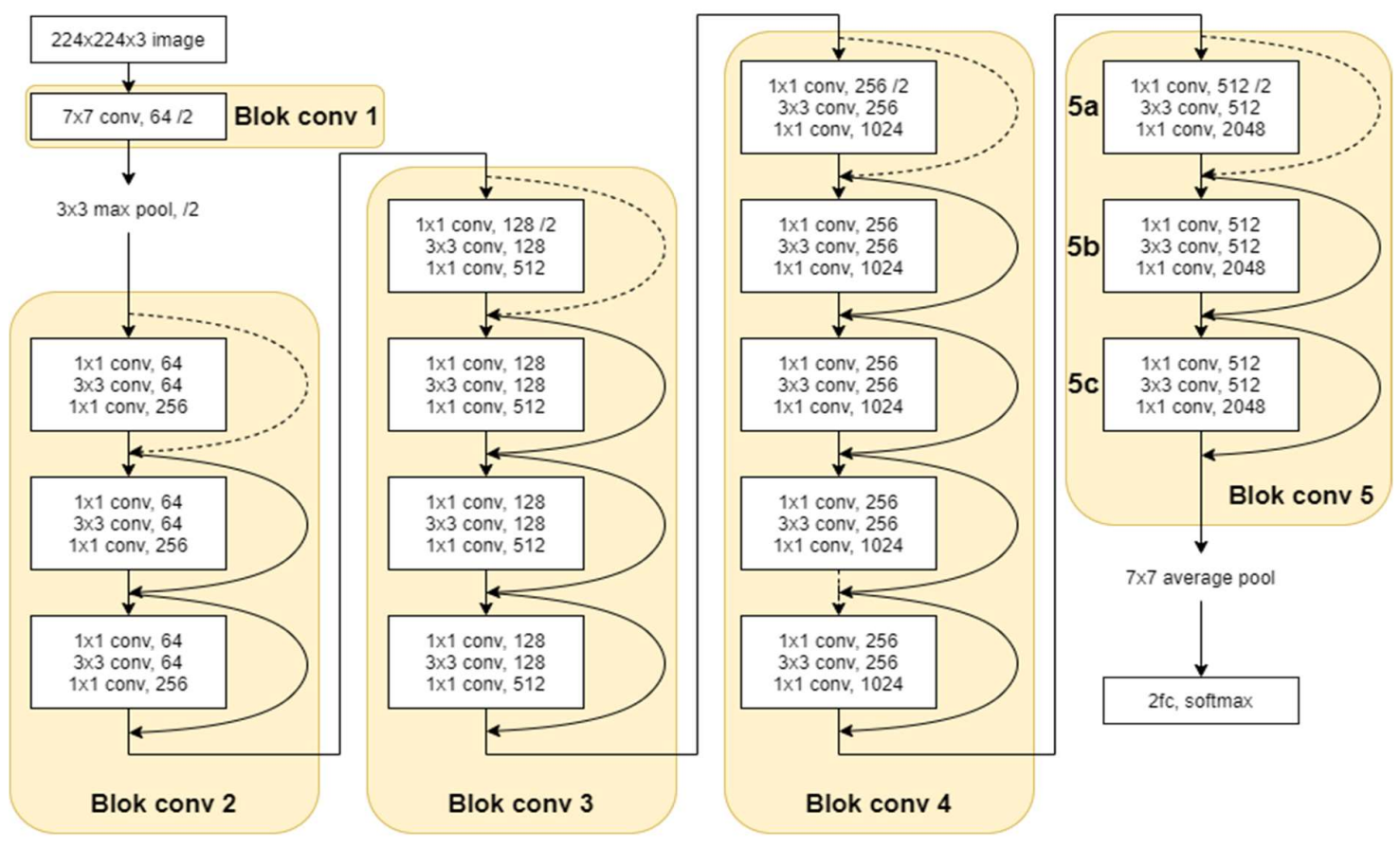

Gambar 3. Arsitektur ResNet-50 dalam sistem yang dibangun 


\subsection{Pengumpulan Dataset}

Data yang yang dipakai dalam studi ini diambil dari dua sumber terbuka terdiri dari data covid19 melalui laman https://github.com/ieee8023/covid-chestxray-dataset dan data normal yang dapat diakses melalui https://www.kaggle.com/paultimothymooney/chest-xray-pneumonia. Dari dua sumber ini, kami kemudian memformulasikan dataset gabungan dengan dua kelas yaitu Covid-19 dan Normal yang masing-masing memiliki jumlah data latih 48 citra dan data validasi masing-masing 15 citra. Sedangkan untuk data uji, kelas Covid-19 sebanyak 42 citra dan kelas normal sebanyak 234 citra.

\subsection{Sistem yang dibagun}

Setelah mengumpulkan dataset, langkah selanjutnya adalah membangun sistem untuk pelatihan dan mengevaluasi jaringan yang dibuat. Pada penelitian ini, kami menggunakan metode transfer learning, yang melakukan proses latih dengan menggunakan model yang sudah terlebih dahulu dilatih menggunakan dataset lain. Untuk kasus ini, kami menggunakan model ResNet yang sudah terlebih dahulu dilatih menggunakan ImagetNet dataset (Deng, dkk, 2009). Diagram alir dari sistem yang kami bangun dapat dilihat di Gambar 4.

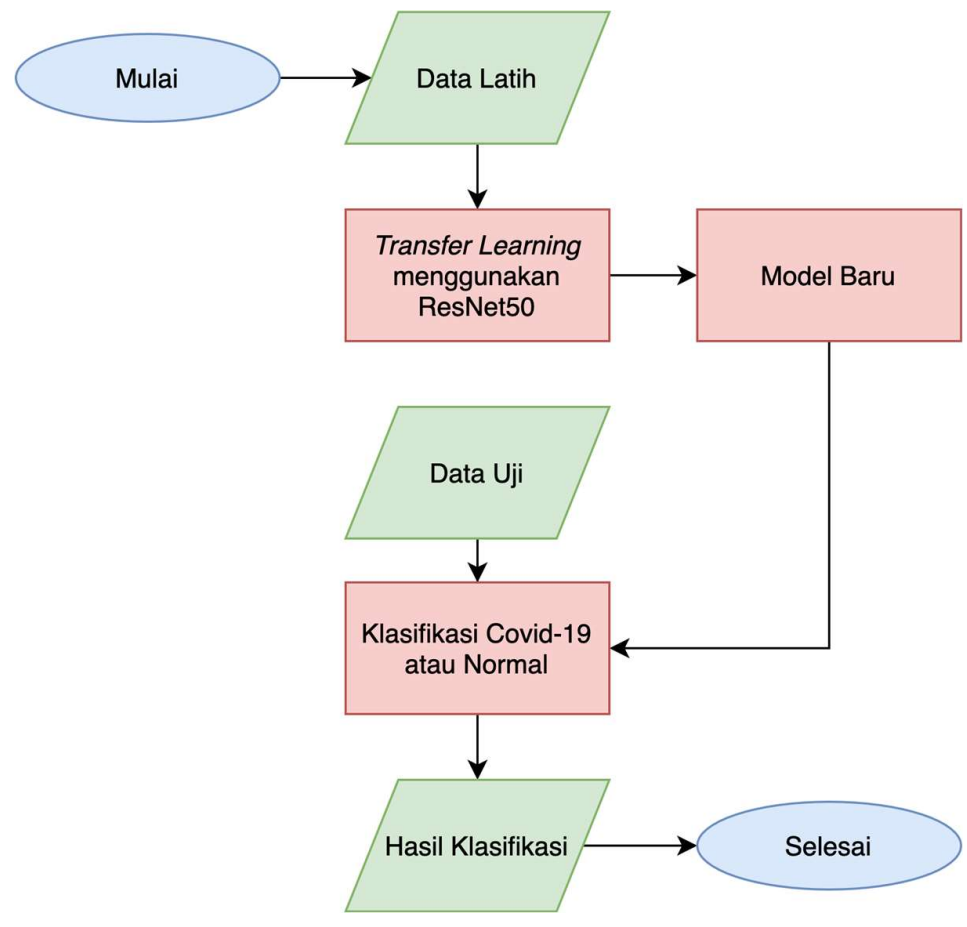

Gambar 4. Diagram Alir dari Proses Latih dan Evaluasi

Arsitektur jaringan yang kami buat berdasarkan dengan model ResNet-50 yang telah dijelaskan di bab 2.2. Yang menjadi dasar perbedaan adalah kami mengubah lapis terakhir dari jaringan tersebut, dari yang awalnya untuk klasifikasi 1000 kelas menjadi hanya 2 kelas yaitu kelas covid19 dan kelas normal. Ada pun gambar rinci dari jaringan yang kami usulkan dapat dilihat di Gambar 3. 


\subsection{Evaluasi}

Metriks yang digunakan untuk mengevaluasi model adalah akurasi, precision, recalldan F1-score. Untuk memahami metriks yang digunakan, sebelumnya akan didefinisikan terlebih dahulu true positive (TP), false positive (FP), false negative (FN) dan true negative (TN) seperti yang ditunjukkan pada confusion matrix Tabel 1. TP didefiniskan sebagai data positif yang diprediksi sebagai positif dan TN didefinisikan sebagai data negatif yang di prediksi sebagai negatif. Sedangkan FN merupakan kebalikan dari TP yaitu data positif yang diprediksi sebagai negatif dan FP, kebalikan dari TN, yaitu data negatif yang diprediksi positif.

Table 1. Confusion Matrix

\begin{tabular}{|c|c|c|c|}
\cline { 3 - 4 } \multicolumn{2}{c|}{} & \multicolumn{2}{c|}{ Kelas sebenarnya } \\
\cline { 3 - 4 } \multicolumn{2}{c|}{} & Positif & Negatif \\
\hline \multirow{3}{*}{ Prediksi } & Positif & True Positive (TP) & False Positive (FP) \\
\cline { 3 - 4 } & Negatif & False Negative (FN) & True Negative (TN) \\
\hline
\end{tabular}

Akurasi didefinisikan sebagai perbandingan jumlah data yang diprediksi secara benar terhadap total jumlah data. Precision menggambarkan perbandingan tp terhadap total data yang diprediksi positif. Recall didefinisikan sebagai perbandingan tp terhadap total data positif. Sedangkan F1score adalah rataan harmonic antara precision dan recall. Persamaan 2, 3, 4, dan 5 merupakan rumus untuk precision, recall, F1-score, dan akurasi.

$$
\begin{aligned}
\text { Precision } & =\frac{T P}{T P+} \\
\text { Recall } & =\frac{T P}{T P+F N} \\
F 1-\text { score } & =\frac{2 * \text { Recall } * \text { Precision }}{\text { Recall }+ \text { Precisio }} \\
\text { Akurasi } & =\frac{T P+T N}{T P+T N+F P+F N}
\end{aligned}
$$

\section{HASIL DAN PEMBAHASAN}

Pada bab ini akan dijelaskan hasil eksperimen dan pembahasannya secara terperinci. Dalam menjalankan simulasi deteksi penyakit Covid-19 ini, digunakan komputer dengan sistem operasi Ubuntu 16.04 yang dilengkapi dengan sebuah GPU Titan X yang memiliki memori 12 GB dan RAM sebesar 32 GB. Simulasi dilakukan dengan bahasa pemrograman Python dan library deep learning Keras (Chollet, dkk, 2015). Dataset dibagi menjadi tiga bagian yaitu data latih, validasi, dan tes. Pembagian dataset ketika simulasi adalah $60 \%$ untuk data latih, $20 \%$ untuk data validasi, dan $20 \%$ untuk data tes. Proses latih dimulai dengan laju kecepatan belajar (learning rate) sebesar $10^{-3}$, optimizer Stochastic Gradient Descent dengan weight 0.0001 decay iterasi selama 30 iterasi. Untuk menambah variasi data dan menghindari overfitting, kami juga menggunakan augmentasi data ketika proses latih yaitu rotasi, menggeser lebar (width shift), menggeser panjang citra (height shift), dan membesarkan citra dengan skala tertentu. Selanjutnya proses 
latih juga menggunakan batch dengan ukuran 16 sampel. Hasil evaluasi dari setiap eksperimen kami menggunakan Persamaan 2, 3, 4, dan 5.

\subsection{Pengaruh terhadap transfer learning}

Pada bagian ini dibahas pengaruh transfer learning terhadap model deep learning yang kami bangun. Terdapat tiga model yang digunakan, yaitu Model A yang merupakan model hasil transfer learning pada Blok $5 \mathrm{C}$ dari ResNet, Model $\mathrm{B}$ adalah model hasil hasil transfer learning pada blok $5 \mathrm{~b}$ dan $5 \mathrm{c}$, dan terakhir Model $\mathrm{C}$ yaitu model hasil transfer learning pada blok $5 \mathrm{a}, 5 \mathrm{~b}$, dan $5 \mathrm{c}$. Penggambaran Blok 5a, 5b, dan 5c dapat dilihat di Gambar 3. Kami mengamati bahwa blok 5 menyimpan high level feature yang cocok dipakai untuk retraining deep learning berbasis citra XRay karena pada blok ini menyimpan informasi yang berguna. Sesuai dengan sub-bab 2.5, kami melaporkan hasil masing-masing model pada Tabel 2, Tabel 3, dan Tabel 4. Kemudian hasil ratarata untuk semua model ditampilkan di Tabel 5 untuk membandingkan setiap komponen evaluasi.

Tabel 2 menjelaskan nilai precision, recall, dan F-1 score dari Model A. Di sini Model A memiliki nilai recall 0.79 yang artinya $79 \%$ dari hanya $97 \%$ prediksi yang positif dari keseluruhan prediksi yang benar. Selanjutnya di Tabel 3, kami melaporkan bagaimana hasil uji jika menggunakan Model B. Hasil recall model B lebih baik dari Model A, namun model B memiliki nilai precision yang lebih rendah untuk mendeteksi kasus Covid-19. Di Tabel 4, kami melaporkan hasil prediksi menggunakan Model $\mathrm{C}$. Model $\mathrm{C}$ memiliki nilai precision, recall, dan F-1 score yang paling tinggi untuk semua kelasnya. Nilai rata-rata precision, recall, dan F-1 score kami laporkan di Tabel 5. Kemudian kami juga melaporkan perbandingan akurasi dari ketiga Model. Model A memiliki akurasi 97\%, Model B memiliki akurasi 97\%, dan Model C memiliki akurasi 99\%. Dari ketiga model yang diusulkan, dilihat dari sisi akurasi dapat disimpulkan bahwa Model $\mathrm{C}$ memiliki performansi yang paling baik. Hal ini dikarenakan penggunaan feature terlatih yang lebih banyak dibandingkan dua model lainnya. Namun demikian, Model C memiliki kekurangan yaitu penggunaan parameter yang lebih banyak.

Table 2. Detail Precision, Recall, F-1 score menggunakan Model A

\begin{tabular}{|c|c|c|c|}
\hline Kelas & Precision & Recall & F1-score \\
\hline Covid-19 & 0.97 & 0.79 & 0.87 \\
\hline Normal & 0.98 & 1.00 & 0.99 \\
\hline
\end{tabular}

Table 3. Detail Precision, Recall, F-1 score menggunakan Model B

\begin{tabular}{|c|c|c|c|}
\hline Kelas & Precision & Recall & F1-score \\
\hline Covid-19 & 0.94 & 0.81 & 0.87 \\
\hline Normal & 0.98 & 0.99 & 0.99 \\
\hline
\end{tabular}

Table 4. Detail Precision, Recall, F-1 score menggunakan Model C (14.9M)

\begin{tabular}{|c|c|c|c|}
\hline Kelas & Precision & Recall & F1-score \\
\hline Covid-19 & 0.97 & 0.90 & 0.94 \\
\hline Normal & 0.99 & 1.00 & 0.99 \\
\hline
\end{tabular}


Hariyani, dkk.

Table 5. Rata-rata Precision, Recall, dan F-1 score untuk semua model

\begin{tabular}{|c|c|c|c|}
\hline Nama Model & Precision & Recall & F1-score \\
\hline Model A & 0.97 & 0.89 & 0.93 \\
\hline Model B & 0.96 & 0.90 & 0.93 \\
\hline Model C & 0.98 & 0.95 & 0.97 \\
\hline
\end{tabular}

Table 6. Akurasi untuk semua model

\begin{tabular}{|c|c|}
\hline Nama Model & Akurasi \\
\hline Model A & $97 \%$ \\
\hline Model B & $97 \%$ \\
\hline Model C & $99 \%$ \\
\hline
\end{tabular}

3.2 Evaluasi prediksi berdasarkan kualitas citra
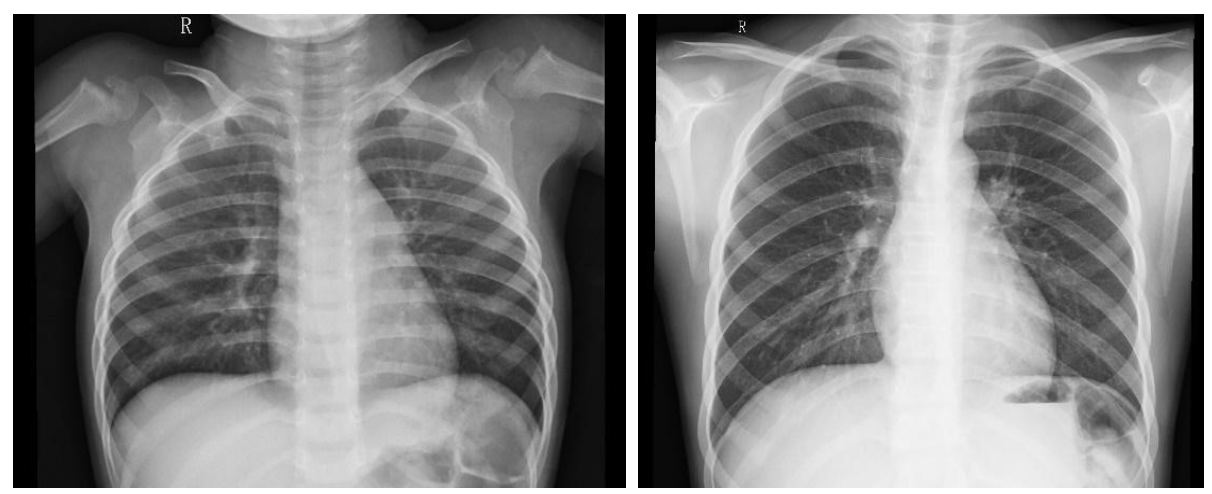

Gambar 5. Citra X-Ray dari Pasien Normal dengan Hasil Prediksi Normal
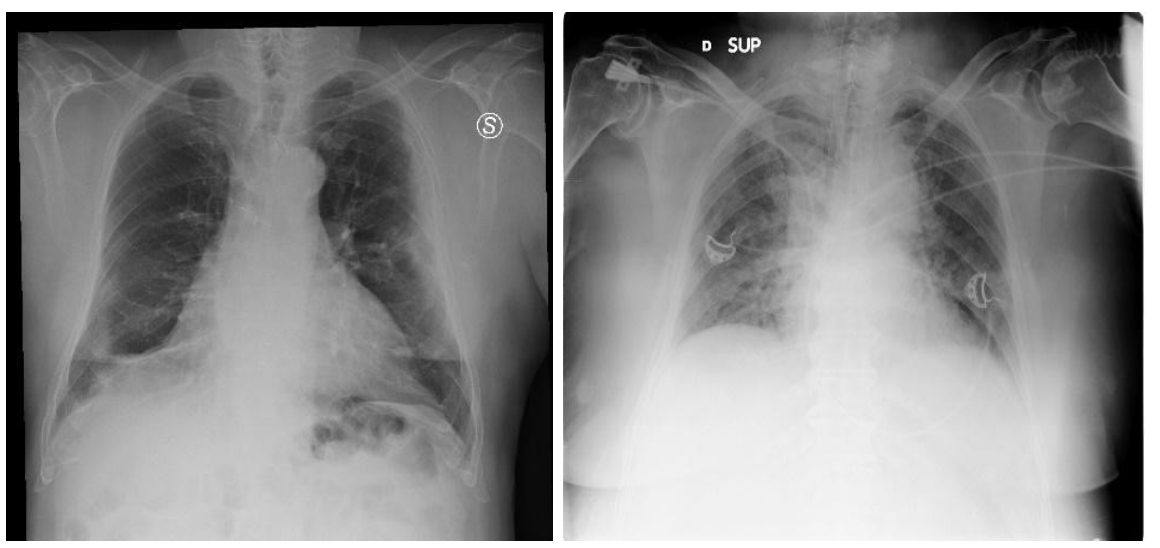

Gambar 6. Citra X-Ray dari Pasien Covid-19 dengan Hasil Prediksi Covid-19 


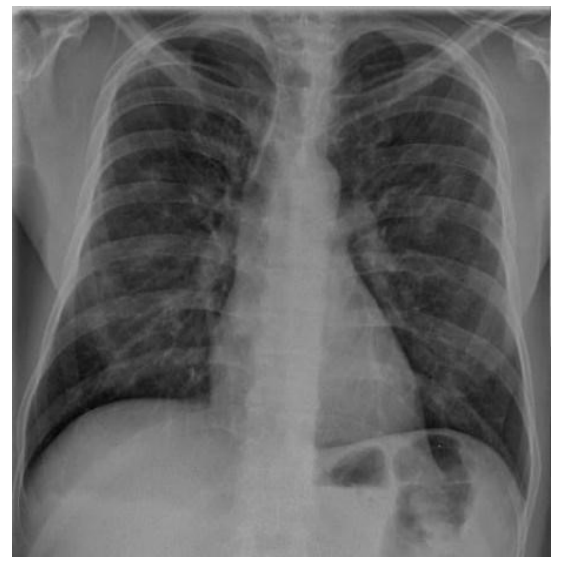

Gambar 7. Contoh Citra X-Ray dengan Kesalahan Klasifikasi

Selain hasil evaluasi pada Tabel 2 hingga Tabel 6, kami juga mencantumkan contoh hasil evaluasi secara visual dengan menggunakan data test. Gambar 5 merupakan contoh citra yang memiliki kelas normal dan hasil prediksi normal. Hasil prediksi untuk citra sebelah kiri yaitu akurasi sebesar 99.65\% dengan Model A, 94.96\% dengan Model B, dan 99.71\% dengan model C. Sedangkan untuk citra sebelah kanan yaitu akurasi sebesar $94.62 \%$ dengan Model A, 50.43\% dengan model 2, dan $95.34 \%$ dengan Model C. Dapat dilihat bawah Model $\mathrm{C}$ memiliki akurasi yang lebih tinggi diantara semua model. Namun hal patut dicermati adalah Model B memprediksi kedua citra dengan nilai akurasi yang lebih rendah.

Gambar 6 merupakan contoh prediksi Covid-19 dengan input kelas Covid-19. Dengan menggunakan Model A dapat memprediksi citra sebelah kiri pada Gambar 6 sebagai Covid-19 dengan akurasi $97.68 \%$. Sedangkan prediksi dengan Model B menghasilkan akurasi $89.77 \%$. Dan Model B memprediksi citra kiri sebagai Covid-19 dengan akurasi $98.16 \%$. Untuk citra sebelah kanan pada Gambar 6, hasil prediksi masing-masing model adalah sebagai berikut Model A memiliki akurasi sebesar 95.55\%, Model B memiliki akurasi sebesar 96.41\%, dan Model C memiliki akurasi sebesar $97.99 \%$.

Selanjutnya kami juga melaporkan hasil kesalahan prediksi menggunakan ketiga model sebagaimana ditunjukkan pada Gambar 7. Masukan kelas sebenarnya adalah Covid-19, namun diprediksi sebagai kelas normal. Berikut akurasi dari masing-masing model yaitu Model A memprediksi normal sebesar $86.59 \%$, Model B sebesar $72.88 \%$, dan Model C sebesar $64.81 \%$. Dapat dilihat bahwa Model C memiliki prediksi yang lebih kecil. Sehingga dari ketiga model dapat disimpulkan bahwa Model $\mathrm{C}$ memiliki performansi yang paling stabil.

\section{KESIMPULAN}

Pada penelitian ini diusulkan metode untuk deteksi COVID-19 berdasarkan citra chest X-Ray. Simulasi dilakukan dua kelompok data citra yaitu COVID-19 dan normal. Arsitektur jaringan yang diusulkan didasarkan pada model ResNet-50 yang mempunyai 50 layer. Kami menggunakan data latih dan data validasi untuk masing-masing kelas sebanyak 48 dan 15 citra. Untuk data uji digunakan 42 citra untuk kelas covid-19 dan 234 citra untuk kelas normal. Proses latih dimulai dengan laju kecepatan belajar (learning rate) sebesar $10^{-3}$, optimizer Stochastic Gradient Descent dengan weight 0.0001 decay iterasi selama 30 iterasi. Evaluasi perfoma metode yang diusulkan diukur melalui precision, recall, F1, dan accuracy. Performa terbaik diperoleh pada Model C 
dimana nilai precision, recall, $F 1$, dan akurasi masing-masing adalah 0,98, 0,95, 0,97 dan 99\%. Hasil penelitian ini cukup baik dimana akurasi yang dicapai lebih besar $95 \%$ dan dapat dipertimbangkan untuk diverifikasi dan divalidasi oleh tenaga medis sehingga ke depannya diharapkan dapat diaplikasikan guna mendukung diagnosa klinis penyakit covid-19 pada populasi yang lebih besar.

\section{DAFTAR RUJUKAN}

Allaouzi, I., \& Ahmed, M. B. (2019). A novel approach for multi-label chest X-Ray classification of common thorax diseases. IEEE Access, 7, 64279-64288. https://doi.org/10.1109/ACCESS.2019.2916849

Boldog, P., Tekeli, T., Vizi, Z., Dénes, A., Bartha, F. A., \& Röst, G. (2020). Risk Assessment of Novel Coronavirus COVID-19 Outbreaks Outside China. Journal of Clinical Medicine, 9 (2). https://doi.org/10.3390/jcm9020571

Chollet, F. (2015). Keras. https://keras.io.

Deng, J., Dong, W., Socher, R., Li, L. J., Li, K., \& Fei-Fei, L. (2009). Imagenet: A large-scale hierarchical image database. IEEE conference on computer vision and pattern recognition (pp. 248-255). https://doi.org/10.1109/CVPR.2009.5206848

He, K., Zhang, X., Ren, S., \& Sun, J. (2016). Deep residual learning for image recognition. Proceedings of the IEEE conference on computer vision and pattern recognition (pp. 770778). https://doi.org/10.1109/CVPR.2016.90

Hosseiny, M., Kooraki, S., Gholamrezanezhad, A., Reddy, S., \& Myers, L. (2020). Radiology Perspective of Coronavirus Disease 2019 (COVID-19): Lessons From Severe Acute Respiratory Syndrome and Middle East Respiratory Syndrome. Cardiopulmonary Imaging - Review, (May), 1-5.

Howard, A., Sandler, M., Chu, G., Chen, L. C., Chen, B., Tan, M., ... \& Le, Q. V. (2019). Searching for mobilenetv3. Proceedings of the IEEE International Conference on Computer Vision (pp. 1314-1324). https://doi.org/10.1109/ICCV.2019.00140

Huang, C., Wang, Y., Li, X., Ren, L., Zhao, J., Hu, Y., ... Cao, B. (2020). Clinical features of patients infected with 2019 novel coronavirus in Wuhan, China. The Lancet, 395(10223), 497-506. https://doi.org/10.1016/S0140-6736(20)30183-5

Huang, G., Liu, Z., Van Der Maaten, L., \& Weinberger, K. Q. (2017). Densely connected convolutional networks. Proceedings of the IEEE conference on computer vision and pattern recognition (pp. 4700-4708). https://doi.org/10.1109/CVPR.2017.243

Liu, K.-C., Xu, P., Lv, W.-F., Qiu, X.-H., Yao, J.-L., Jin-Feng, G., \& Wei-Wei. (2020). CT manifestations of coronavirus disease-2019: a retrospective analysis of 73 cases by 
Deteksi Penyakit Covid-19 Berdasarkan Citra X-Ray Menggunakan Deep Residual Network

disease severity. European Journal of Radiology, (February), 108941. https://doi.org/https://doi.org/10.1016/j.ejrad.2020.108941

Mckeever, Amy. (nationalgeographic). (2020). Coronavirus is officially a pandemic. Here's why that matters.

Narin, A., Kaya, C., \& Pamuk, Z. (2020). Automatic Detection of Coronavirus Disease (COVID-19) Using X-ray Images and Deep Convolutional Neural Networks. arXiv preprint arXiv:2003.10849.

Singh, S., \& Krishnan, S. (2019). Filter Response Normalization Layer: Eliminating Batch Dependence in the Training of Deep Neural Networks. arXiv preprint arXiv.1911.09737.

Simonyan, K., \& Zisserman, A. (2014). Very deep convolutional networks for large-scale image recognition. arXiv preprint arXiv: 1409.1556.

Wang, D., Hu, B., Hu, C., Zhu, F., Liu, X., Zhang, J., ... Peng, Z. (2020). Clinical Characteristics of 138 Hospitalized Patients with 2019 Novel Coronavirus-Infected Pneumonia in Wuhan, China. JAMA - Journal of the American Medical Association, 323(11), 1061-1069. https://doi.org/10.1001/jama.2020.1585

Wang, W., Xu, Y., Gao, R., Lu, R., Han, K., Wu, G., \& Tan, W. (2020). Detection of SARS-CoV-2 in Different Types of Clinical Specimens. Jama, 3-4. https://doi.org/10.1001/jama.2020.3786

Xu, X., Jiang, X., Ma, C., Du, P., Li, X., Lv, S., ... Wu, W. (2020). Deep Learning System to Screen Coronavirus Disease 2019 Pneumonia. Medical Physics, 1-29. Retrieved from http://arxiv.org/abs/2002.09334

Yoon, S. H., Lee, K. H., Kim, J. Y., Lee, Y. K., Ko, H., Kim, K. H., ... Kim, Y.-H. (2020). Chest Radiographic and CT Findings of the 2019 Novel Coronavirus Disease (COVID-19): Analysis of Nine Patients Treated in Korea. Korean Journal of Radiology, 21(4), 494-500. https://doi.org/10.3348/kjr.2020.0132

Zhu, Y., Liu, Y.-L., Li, Z.-P., Kuang, J.-Y., Li, X.-M., Yang, Y.-Y., \& Feng, S.-T. (2020). Clinical and CT imaging features of 2019 novel coronavirus disease (COVID-19). The Journal of Infection, S0163-4453(20)30104-3. https://doi.org/10.1016/j.jinf.2020.02.022 